\title{
Substitution of soyabean meal with " 00 ” rapeseed meal or its high-protein fraction in the nutrition of hens laying brown-shelled eggs
}

\author{
B.Z. Kamińska \\ Research Institute of Animal Production, Department of Feed Sciences \\ 32-083 Balice, Poland
}

(Received 16 September 2002; accepted 20 December 2002)

\begin{abstract}
One hundred and seventy-five laying hens each of lines Hy-Line and ISA Brown were divided into seven groups of 25 birds and maintained in individual cages from the age of 26 weeks for 9 months of laying. The hens were fed isoprotein and isocaloric diets containing $16.7 \%$ crude protein and $11.4 \mathrm{MJ} / \mathrm{kg}$. In the experimental diets, 45,60 or $100 \%$ of the protein of soyabean meal was replaced by protein from regular rapeseed meal (R-RSM) or fractionated rapeseed meal (S-RSM) containing $11 \%$ more protein and $14 \%$ less crude fibre. Every 8 weeks egg and egg shell quality were assessed on 15 eggs per group; twice during the experiment egg odour was assessed on eggs from all of the hens. The use of rapeseed meal, both R-RSM and S-RSM, had no effect on laying rate parameters of egg and egg shell quality. As the content of rapeseed meal in the diet increased, the weight of eggs decreased $(\mathrm{P}<0.01)$. Among the hens fed the ration containing rapeseed meal, 3.4\% of the Hy-Line and $7.4 \%$ of the ISA Brown hens laid eggs with a fishy odour. The type of rapeseed meal and its content in the diets had no effect on the occurrence or intensity of the non-specific odour of eggs.
\end{abstract}

KEY WORDS: rapeseed meal, laying performance, egg quality, egg taint

\section{INTRODUCTION}

Rapeseed meal, one of the main sources of protein in animal nutrition, has a lower nutritive value than soyabean meal because of its lower protein content and higher crude fibre content, and because it contains glucosinolates, which are antinutrients. 
The use of rapeseed meal in the nutrition of broilers is more common (Smulikowska et al., 1991, 1998; Chibowska et al., 2000; Kamińska et al., 2000), than in laying hens (Rutkowski et al., 1989; Gwara et al., 1993; Brettschneider et al., 1995; Niemiec et al., 2001). This may be caused by the occurrence of the unpleasant "fishy" odour of eggs from some hens fed rapeseed meal. In reviews on the occurrence of egg taint, Pearson et al. (1980) and Butler et al. (1982) found that it is related to the presence of sinapine in rape seed and reduced trimethylamine oxidaze activity in the liver of those hens that lay brown-shelled eggs. These layers lack the gene that is responsible for the degradation of trimethylamine, a compound with a fishy odour, that is formed in the bacterial hydrolysis of synapine. Ochodzki (2002) reported, that yellow-seed varieties of rapeseed contain more synapine (2.3-2.9\%) than the brown-seed (2.1-2.2\%). This is why the use of yellow-seed varieties is rather ineffective in preventing the production of tainted eggs.

The objective of this study was to examine the effect of partial or total substitution of soyabean meal with regular rapeseed meal or its fraction, which as a result of mechanical separation contains more protein and less crude fibre, on the productivity of laying hens and the quality of eggs of two lines of hens laying brown-shelled eggs.

\section{MATERIAL AND METHODS}

Rapeseed meal (R-RSM) was separated using a $0.5 \mathrm{~mm}$ mesh sieve. Two fractions were obtained of which the finer one, containing more crude protein and less crude fibre, is denoted as S-RSM and was used in the diets of laying hens.

The experiment was conducted on Hy-Line and ISA Brown laying hens, 175 hens of each strain, divided into 7 groups of 25 hens. The birds were kept in individual cages from 26 weeks of age for a 9-month laying period.

The hens were fed isoprotein and isocaloric diets containing $16.7 \%$ crude protein and $11.4 \mathrm{MJ} \mathrm{EM} / \mathrm{kg}$ (Table 1). The control feed contained $15 \%$ soyabeanmeal and $14 \%$ wheat bran. In the experimental groups, 45,60 or $100 \%$ of the protein from the soyabean meal and wheat bran was replaced by R-RSM or S-RSM protein. During the experimental period, at the age of 40 and 58 weeks daily feed consumption was measured over four consecutive days, individually for each hen.

On weeks 30, 38, 46, 54 and 62 of life the quality of eggs and egg shells was estimated in 15 eggs from each group, if possible from the same birds. A total of 1050 eggs was examined. The eggs were weighted, their specific gravity was measured by submerging in $\mathrm{NaCl}$ solutions, and breaking strength (on the long axis), weight of yolk, and dry shell and shell thickness (at three points) were assessed according to the methods described by Kamińska et al. (1996). Mean shell thickness and percentage of shell and yolk in egg were calculated. Twice during the experiment the odour of eggs sampled from all of the hens was assessed by a four-member panel. 
TABELA 1

Composition of diet, $\mathrm{g} / \mathrm{kg}$

\begin{tabular}{lccccccc}
\hline Group & 1 & 2 & 3 & 4 & 5 & 6 & 7 \\
\hline Wheat & control & & & & & & \\
Wheat bran & 359 & 380 & 390 & 372 & 371 & 394 & 388 \\
Soyabean meal (46\% CP) & 140 & 100 & 80 & 70 & 120 & 90 & 80 \\
R-RSM $^{1}$ & 150 & 70 & 50 & - & 70 & 50 & - \\
S-RSM $^{2}$ & - & 90 & 120 & 190 & - & - & \multicolumn{1}{c}{} \\
Meat meal (60\% CP) & - & - & - & - & 80 & 110 & 170 \\
Fat & 25 & 35 & 35 & 40 & 32 & 31 & 32 \\
Constant components & 30 & 30 & 30 & 35 & 32 & 30 & 35 \\
& 296 & 295 & 295 & 293 & 295 & 295 & 295 \\
Calculated & & & & & & & \\
$\quad$ EM MJ/kg & 11.38 & 11.42 & 11.43 & 11.45 & 11.42 & 11.44 & 11.48 \\
CP & 167.5 & 166.6 & 166.3 & 167.6 & 166.2 & 166.5 & 165.6 \\
lys & 7.5 & 7.2 & 7.2 & 7.2 & 7.3 & 7.4 & 7.4 \\
met + cys & 5.9 & 6.4 & 6.6 & 7.1 & 6.3 & 6.5 & 6.8 \\
crude fibre & 37.3 & 43.7 & 45.8 & 52.2 & 40.4 & 41.1 & 44.1 \\
Ca & 31.6 & 32.1 & 32.2 & 32.1 & 31.9 & 31.9 & 32.2 \\
P available & 3.2 & 3.5 & 3.5 & 3.5 & 3.5 & 3.4 & 3.5 \\
\hline
\end{tabular}

${ }^{1} \mathrm{R}-\mathrm{RSM}$ - regular rapeseed meal

${ }^{2} \mathrm{~S}-\mathrm{RSM}$ - separated fraction of R-RSM containing more crude protein and less crude fibre

${ }^{3}$ suppling per kg diet: maize 200, meat-and-bone meal 10, dicalcium phosphate 4, limestone 73 (except of group 1-74 and group 4-71), $\mathrm{NaCl} 3$, and mineral-vitamin premix 5

The chemical composition of feeds was determined using standard methods (AOAC, 1990), the amino acid content, with the exception of tryptophan, was determined using a Carlo Erba automatic analyzer. Sulphur-containing amino acids were oxidized before hydrolysis. The glucosinolate content was analyzed by HPLC according to the ISO-9167 method (1991).

The results were subjected to 3-way ANOVA (GLM) analysis (SAS Institute, 1985).

\section{RESULTS}

S-RSM accounted for $35 \%$ of the R-RSM taken for fractionation. It contained $11 \%$ more protein and $14 \%$ less crude fibre than R-RSM (Table 2). Total glucosinolates equaled $9.97 \mu \mathrm{M} / \mathrm{g}$ of fat-free OM of R-RSM, and increased to 11.82 $\mu \mathrm{M} / \mathrm{g}$ in S-RSM.

In S-RSM protein the percentage of methionine and cystine was lower than in R-RSM protein (Table 3 ). The crude fibre content equaled 3.7\% in the control diet and from 4.0 to $5.2 \%$ in the experimental diets (Table 1). 
TABELA 2

Chemical composition of soyabean meal and rapeseed meals, g/kg DM

\begin{tabular}{lccccccc}
\hline Meal & $\begin{array}{c}\text { Dry } \\
\text { matter }\end{array}$ & Ash & $\begin{array}{c}\text { Crude } \\
\text { protein }\end{array}$ & $\begin{array}{c}\text { Ether } \\
\text { extract }\end{array}$ & $\begin{array}{c}\text { Crude } \\
\text { fibre }\end{array}$ & $\begin{array}{c}\text { N-free } \\
\text { extractives }\end{array}$ & $\begin{array}{c}\mathrm{GLS}^{1} \\
\mu \mathrm{M} / \mathrm{g} \\
\text { deffated } \\
\text { DM }\end{array}$ \\
\hline Soyabean meal & 879 & 70 & 512 & 20 & 113 & 285 & - \\
Rapeseed meal & 887 & 77 & 398 & 30 & 157 & 338 & 9.97 \\
Separated rapeseed meal & 891 & 81 & 441 & 23 & 135 & 319 & 11.82 \\
\hline
\end{tabular}

${ }^{1}$ GLS - glucosinolates

TABELA 3

Amino acid composition of rapeseed meal and its fine faction, $\mathrm{g} / 16 \mathrm{~g} \mathrm{~N}$

\begin{tabular}{lrc}
\hline Amino acid & R-RSM & S-RSM \\
\hline Lys & 5.60 & 5.44 \\
Met & 2.85 & 1.88 \\
Cys & 3.57 & 2.64 \\
Tre & 4.98 & 4.92 \\
Val & 4.92 & 5.02 \\
Arg & 6.19 & 5.74 \\
Gly & 5.38 & 5.45 \\
Ser & 4.77 & 4.73 \\
His & 2.77 & 3.83 \\
Ileu & 3.73 & 3.84 \\
Leu & 7.45 & 7.39 \\
Phe & 4.24 & 5.56 \\
Tyr & 2.63 & 3.93 \\
\hline
\end{tabular}

At the beginning of the experiment the average weight of the ISA Brown hens was $1.54 \mathrm{~kg}$, at the end $1.74 \mathrm{~kg}$; it was on average 140 and $240 \mathrm{~g}$ less, respectively, than the Hy-Line birds. The weight of the hens within each line was uniform; there were no significant differences between groups. The average daily feed intake of ISA Brown hens was $113 \mathrm{~g}$ and Hy-Line $120 \mathrm{~g}$.

It was found that there was a highly significant difference in the average laying rate between Hy-Line (88\%) and ISA Brown (91.9\%) hens (Table 4), as well as in the weight of eggs, which was higher in Hy-Line $(60.7 \mathrm{~g})$ than in ISA Brown $(59.9 \mathrm{~g})$. The general weight of the eggs laid over 9 months was, however, higher in ISA Brown hens and equaled on average $15.1 \mathrm{~kg}$ per hen, whereas in Hy-Line hens $14.7 \mathrm{~kg}$.

No significant differences were found in the laying rate resulting from substituting soyabean meal with rapeseed meal, even when the soyabean meal was completely replaced (group 4). Highly significant differences were found, however, in egg weight depending on the amount of rapeseed meal in the diet; as the amount 


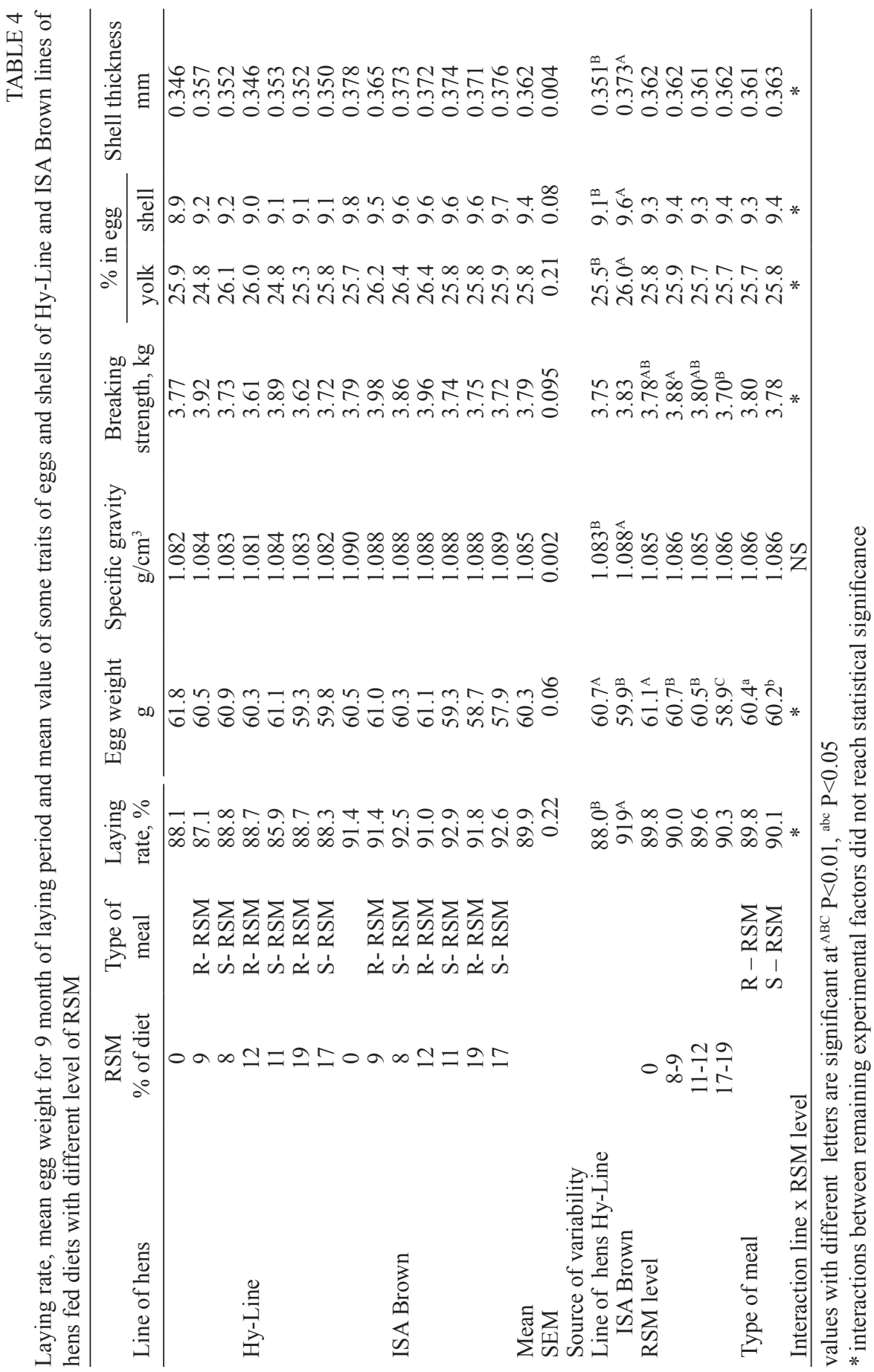


of rapeseed meal increased, egg weight decreased (Table 4). Introducing fraction S-RSM with a higher protein content and somewhat higher level of glucosinolates caused a slight, although significant $(\mathrm{P}<0.05)$, reduction in egg weight in comparison with the R-RSM diet (60.2 vs $60.4 \mathrm{~g}$ ).

A significant difference $(\mathrm{P}<0.01)$ was found in the specific gravity of eggs, egg yolk and egg shell percentage, egg weight and shell thickness only between lines of hens (Table 4). Increasing the amount of rapeseed meal in the diet did not affect the egg yolk percentage or egg shell quality (Table 4). The type of rapeseed meal also had no effect on any of the studied traits of the eggs.

It was found that 6 of the Hy-Line hens in groups 3-6 and 13 ISA Brown hens, 2 - 3 in each group with the exception of the group 4, laid eggs with an unpleasant fishy odour. No such eggs were found in control group.

\section{DISCUSSION}

The fine fraction of rapeseed meal making up 35\% of R-RSM contained 44\% protein and $13.5 \%$ crude fibre in dry matter (Table 2). By sieving rapeseed meal through a $0.3 \mathrm{~mm}$ mesh sieve Korniewicz et al. (1999) obtained a fraction that made up $30 \%$ of the material and contained $42 \%$ protein and $9 \%$ crude fibre in dry matter. Similarly as of experiment of Kamińska et al. (2000), the protein in S-RSM contained less methionine and cystine than the R-RSM.

In both experiments the total glucosinolate content (GLS) was higher in S-RSM than in R-RSM. This (limits of GLS) amount was however, much lower than limits of GLS in rapeseed meals, which equals $20 \mu \mathrm{M} / \mathrm{g}$ dry matter. Also Korniewicz et al. (1999) found that the coarse fraction contained $35 \%$ less isothiocyanates than the fine fraction of rapeseed meal.

The use of such even high amounts of rapeseed meal as 17 and 19\% of diets did not reduce the laying rate of hens in either of the lines. The average egg weight did, however, decline; in Hy-Line hens from $61.8 \mathrm{~g}$ in the control group to $59.3 \mathrm{~g}$ and to $59.8 \mathrm{~g}$ (when soyabean meal was totally replaced by R-RSM and S-RSM), whereas in ISA Brown hens, from $60.5 \mathrm{~g}$ in the control group to 57.9 and $58.7 \mathrm{~g}$.

Smulikowska and Buraczewski (1991) reported, that feeding White Leghorn hens with diets containing 10 or $16 \%$ rapeseed meal did not affect the laying rate, but did lower the average weight of eggs from $62.3 \mathrm{~g}$ in the control group to 61.1$61.6 \mathrm{~g}$. Elwinger and Saterby (1986) also reported a reduction in egg weight when 4.5, 9.0 and $14.5 \%$ canola meal was included into diets. Wetscherek et al. (1991) found a reduction in the average weight of eggs in hens fed $10 \%$ canola meal, while at the same time the number of damaged shells decreased by $0.4-0.5 \%$.

In the current study the inclusion of small amounts of rapeseed meal into diet caused a highly significant $(\mathrm{P}<0.01)$ reduction of egg weight in comparison with 
control group (60.7 vs $61.1 \mathrm{~g}$ ). Egg yolk weight declined proportionally to the weight of the whole egg, and the percentages of yolk, egg white and egg shell in the egg were similar.

Niemiec et al. (2001) showed, that the inclusion of $8 \% 00$ rapeseed in the diets for 3 meat lines of hens did not cause statistically significant differences in the number of eggs laid or in their weight. Only in Astra W hens, which had higher feed intake and somewhat lower laying rate, reduction in the percentage of egg yolk in the egg weight was significant $(\mathrm{P}<0.05)$.

Rutkowski et al. (1989) reported that the odour of eggs from Astra S hens fed diets containing 19\% 00 rapeseed meal deteriorated. However hens were not considered individually and the results were presented as averages for the group. Brettschneider et al. (1995) studied the level of trimethylamine (TMA) in the yolks of eggs from hens laying brown-shelled eggs depending on the share of heated rape seeds in the diet (7.5-30\%). At a 7.5\% share of seeds in the diet, the TMA content was low in comparison with the control group. The authors did not, however, report the line studied and did not investigate the effect of the amount of TMA in egg yolks on the odour of eggs. At a 15\% rape seed in diet, the laying rate and egg weight did not change.

Niemiec et al. (2001), evaluating the brown-shelled eggs laid by Astra S and Messa 245 hens and white-shelled eggs laid by Astra W hens fed diets containing $8 \% 00$ rape seeds, did not reported the occurrence of the nonspecific fishy odour.

In experiments in which eggs are randomly sampled for organoleptic evaluation, it is not possible to determine the number of hens per flock with a genetic defect hindering liver TMA metabolism.

In the presented study, the genetic defect manifested itself even at a relatively low level of rapeseed meal in the diet. It was, however, a higher level than recommended by Smulikowska (1992), who reccomended that the level of rapeseed meal in diets for hens laying brown-shelled eggs may amount from 3 to $5 \%$. In the feeding of hens laying white eggs, the recommended levels are 10 and $15 \%$, respectively, because this genetic defect does not occur in hens laying white eggs.

In hens receiving 8-9\% rapeseed meal, egg taint was found in 2-3 birds per group. Not even one hen with this defect was found among ISA Brown hens fed 19\% R-RSM or among Hy-Line hens fed 17\% S-RSM. Overall, 7.4\% of ISA Brown and $3.4 \%$ of Hy-Line hens laid eggs with a fishy smell.

An increase in the protein content and reduction of crude fibre in mechanically fractionated rapeseed meal was relatively low, and the use of S-RSM fraction in diets did not give better results than regular rapeseed meal. It can therefore be concluded that fractionation did not give the expected benefits.

Chibowska et al. (2000) found, moreover, that lowering the level of fibre and increasing the share of protein in rapeseed meal by mechanical separation is a costly and economically unjustified process. Rotkiewicz and Zadernowski (1997) believe 
that it would be more beneficial to remove the seed coat of rapeseed before oil is pressed. This would allow not only increase in the nutritional value of the meal, but also improve the quality of the oil.

\section{CONCLUSIONS}

Introducing rapeseed meal into the diets for laying hens lowers the weight of eggs $(\mathrm{P}<0.01)$. In amounts up to $12 \%$ RSM in the feed, this reduction is small, but at level of $17-19 \%$ the weight of eggs may decline by about $10 \%$.

Neither the level of RSM nor its type (regular or separated) have an effect on laying rate, percentage of yolk and shell in egg weight, or quality parameters of the egg shell.

The use in diet the fine fraction of RSM with higher protein and lower crude fibre level does not improve performance of laying hens.

Among ISA Brown hens there are over twice as many birds as among Hy-Line that carry the genetic defect allowing trimethylamine to pass into eggs, giving them an unpleasant fishy odour.

\section{REFERENCES}

AOAC, 1990. Official Methods of Analysis, Association of Analytical Chemist. $15^{\text {th }}$ Edition. Washington, DC

Brettschneider J., Dänicke S., Jeroch H., 1995. The influence of graded levels of rapeseed in laying hen diets on egg quality with special consideration of hydrotermal treatment of rapeseed In: R.C. Briz (Editor). Proceedings of VI European Symposium on the Quality of Eggs and Egg Products. Zaragoza (Spain), pp. 227-232

Butler E.J., Pearson A.W., Fenwick G.R., 1982. Problems which limit the use of rapeseed meal as a protein source in poultry diets. J. Sci. Food Agr. 33, 866-875

Chibowska M., Smulikowska S., Pastuszewska B., 2000. Metabolisable energy value of rapeseed meal and its fraction for chickens as affected by oil and fibre content. J. Anim. Feed Sci. 9, 371-378

Elwinger K., Saterby B., 1986. Continued experiments with rapeseed meal of a Swedish low glucosinolate type fed to poultry. Swedish J. Agr. Res. 16, 35-41

ISO-9167-1, Polish Standard, 1991. HPLC Method of Glucosinolates Determination (in Polish)

Gwara T., Mazanowska A., Kinal S., Fritz Z., 1993. Effect of twice improved rapeseed meal on productive indices of laying hens and egg hatchability (in Polish). Rocz. Nauk. Zoot., Monogr. Rozpr. 32, 243-254

Kamińska B.Z., Skraba B., Koreleski J., 1996. Effect of dietary phosphorus level and supplemental phytase on performance of Hisex Brown laying hens and egg shell quality. J. Anim. Feed Sci. $5,249-259$

Kamińska B.Z., Brzóska F., Skraba B., 2000. High-protein fraction of 00 type rapeseed meal in broiler nutrition. J. Anim.Feed Sci. 9, 123-136 
Korniewicz A., Chrząszcz E., Czarnik-Matusewicz H., Paleczek B., 1999. Utilization of coarse rapeseed meal fraction in feeding dairy cows ( in Polish). Rośliny Oleiste. 20, (1), 221-232

Niemiec J., Stępińska M., Świerczewska E., Lenartowicz A., Riedel J., 2001. The effect of rapeseed „00" in diet on laying performance and egg quality in Astra S, Astra W and Messa 245 commercial chicken strains (in Polish). Prace Mat. Zoot. 58, 87-94

Ochodzki P., 2002. Variability in synapine content in cruciferous seeds (in Polish). Proceedings of XXIV Conference Oilseed Crops. Plant Breeding and Acclimatization Institute, Poznań, pp. $22-23$

Pearson A.W., Butler E. J., Fenwick G.R., 1980. Rapeseed meal and egg taint. The role of sinapine. J. Sci. Food Agr. 31, 898-904

Rotkiewicz D., Zadernowski R., 1997. Dehulling of rape seed (in Polish). Rośliny Oleiste 18, 493-504

Rutkowski A., Gawęcki K., Matyniak J., 1989. Rapeseed meal of Jantar variety and field pea as substitutes for soybean meal in diets with wheat, triticale or rye for laying hens (in Polish). Zesz. Nauk. Drob. 6, 41-54

Statistical Analysis System User's Guide: Statistics, 1985. SAS Institute Inc., Cary, NC

Smulikowska S., 1992. Using of rapeseed meal, cake or seeds from „00” variety in poultry nutrition (in Polish). In: B. Pastuszewska (Editor). Rapeseed in Animal Nutrition. The Kielanowski Institute of Animal Physiology and Nutririon, Jabłonna, pp.12-17

Smulikowska S., Buraczewski S., 1991. Low glucosinolate rapeseed meal (00) in nutrition of laying hens (in Polish). Prz. hod. 9, 17-18

Wetscherek W., Zolltisch W., Lettner F., 1991. Use of canola meal in diets for laying hens. Proceedings of $8^{\text {th }}$ European Symposium on Poultry Nutrition, Venezia-Mestre (Italy), pp. 314-316

\section{STRESZCZENIE}

\section{Zastąpienie śruty sojowej śrutą rzepakową „00” lub jej frakcją o większej zawartości białka w żywieniu kur znoszących jaja o brązowych skorupach}

Kury Hy-Line i ISA Brown, po 175 niosek z każdej linii, podzielono na 7 grup po 25, i od 26 tygodnia życia utrzymywano pojedynczo w klatkach przez 9 miesięcy nieśności. Nioski żywiono mieszankami izobiałkowymi i izoenergetycznymi, zawierającymi 16,7\% białka ogólnego i 11,4 MJ/kg. W dietach doświadczalnych 45, 60 lub 100\% białka śruty sojowej zastapiono białkiem śruty rzepakowej standardowej lub frakcjonowanej, o zwiększonej o 11\% zawartości białka i o $14 \%$ obniżonej zawartości włókna surowego. Co 8 tygodni oceniano jakość jaj i skorup, każdorazowo na 15 jajach z grupy, dwukrotnie, w czasie trwania doświadczenia, badano zapach jaj od wszystkich kur. Zastosowanie śruty rzepakowej, zarówno standardowej jak i jej frakcji stanowiącej 35\% materiału wyjściowego, nie miało wpływu na tempo nieśności ani na cechy jakości jaj i skorup. Wraz ze wzrostem zawartości śruty rzepakowej w diecie zmniejszała się jednak masa jaj $(\mathrm{P}<0,01)$. Wśród kur otrzymujących w diecie śrutę rzepakową 3,4\% Hy-Line i 7,4\% ISA Brown znosiło jaja o rybim zapachu. Zawartość śruty rzepakowej w diecie i jej rodzaj nie miały wpływu na występowanie oraz intensywność niespecyficznego zapachu w jajach. 